\title{
Characteristics of caregivers submitted to music therapy after the death of loved ones
}

\author{
Características de cuidadores submetidos à musicoterapia após a morte de seus entes queridos
}

Características de cuidadores sometidos a la musicoterapia después de la muerte de sus seres queridos

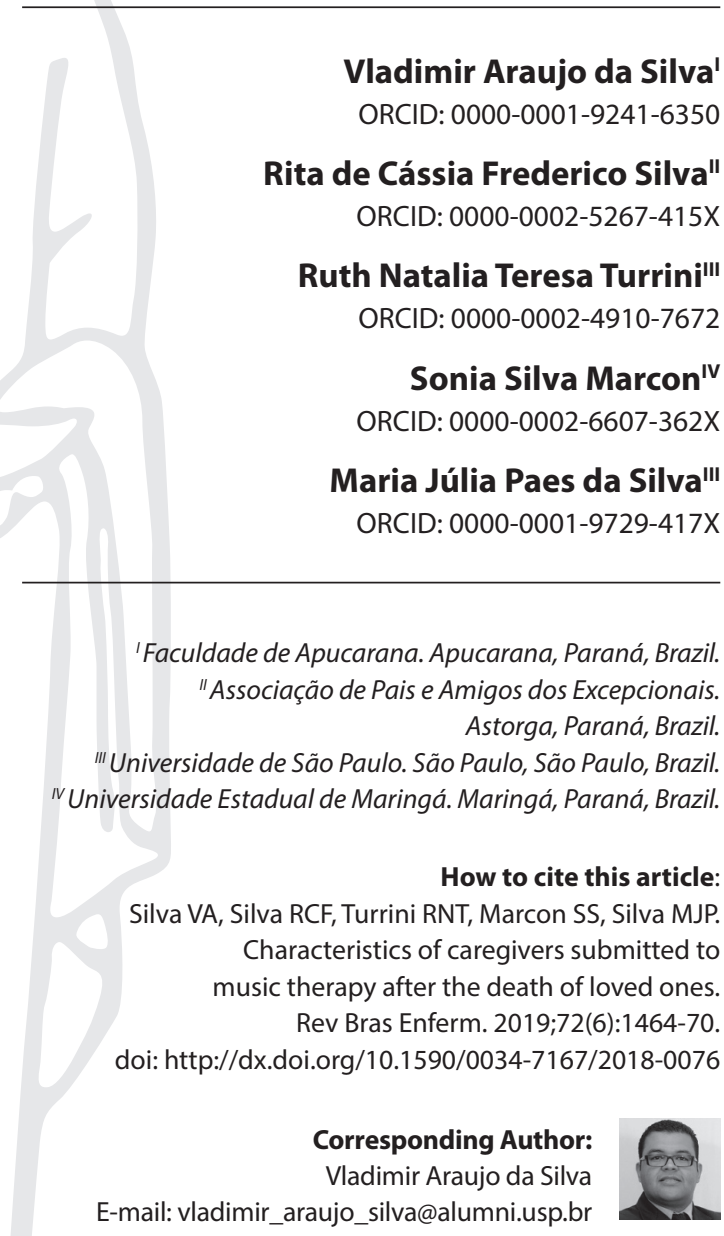

Submission: $02-23-2018$

Approval: 02-18-2019

\begin{abstract}
Objective: To describe the characteristics of bereaved caregivers submitted to post-loss music therapy. Method: This is a cross-sectional database from a randomized clinical trial that performed music therapy for caregivers who lost their loved ones to cancer. The following variables were used for this analysis: sociodemographic, religious beliefs, previous sound-musical experiences, and experiences related to care, loss and repair processes. Descriptive statistical analyzes were performed. Results: Of the 69 participants, $85.5 \%$ had a strong bond/secure attachment with their loved ones; $68.1 \%$ followed a long death and dying process ( $>6$ months), which was related to a chronic disease; $88.4 \%$ did not participate in conspiracy of silence, suggesting a satisfactory communication; $60.9 \%$ reported receiving spiritual/religious support, suggesting healthy and continent support; and all participated in funeral rites. Conclusion: The process of elaborating the bereavement of caregivers indicated the presence of protective factors.

Descriptors: Death; Bereavement; Palliative Care; Caregivers; Music Therapy.
\end{abstract}

\section{RESUMO}

Objetivo: Descrever as características de cuidadores enlutados submetidos à musicoterapia pós-perda. Método: Trata-se de um corte transversal do banco de dados de um ensaio clínico randomizado que realizou musicoterapia para cuidadores que perderam seus entes queridos por câncer. Para esta análise utilizaram-se as seguintes variáveis: sociodemográficas, crenças religiosas, experiências sonoro-musicais pregressas e vivências relacionadas aos processos de cuidado, perda e reparação. Foram realizadas análises estatísticas descritivas. Resultados: Dos 69 participantes, $85,5 \%$ tinham um vínculo forte/ apego seguro com os seus entes queridos; $68,1 \%$ acompanharam um processo de morte e morrer longo ( $>6$ meses), cuja morte está relacionada a uma doença crônica; $88,4 \%$ não participaram de conspiração de silêncio, sugerindo uma comunicação satisfatória; 60,9\% referiram estar recebendo apoio espiritual/religioso, sugerindo apoio saudável e continente; e todos participaram de rituais fúnebres. Conclusão: $O$ processo de elaboração do luto dos cuidadores indicou a presença de fatores de proteção.

Descritores: Morte; Luto; Cuidados Paliativos; Cuidadores; Musicoterapia.

\section{RESUMEN}

Objetivo: Describir las características de los cuidadores sometidos a la musicoterapia durante el luto. Método: Se trata de un corte transversal del banco de datos de un ensayo clínico aleatorizado, en el cual utilizó la musicoterapia en cuidadores que perdieron a sus seres queridos por cáncer. Para este análisis, se utilizaron las siguientes variables: sociodemográficas, creencias religiosas, experiencias sonoras y musicales previas, y vivencias relacionadas a los procesos de cuidado, pérdida y reparación. Se realizó un análisis estadístico descriptivo. Resultados: De los 69 participantes, el 85,5\% tenían un vínculo fuerte/apego seguro con sus seres queridos; el 68,1\% acompañaron un proceso de muerte y morir largo ( $>6$ meses), cuya muerte estuvo relacionada a una enfermedad crónica; el $88,4 \%$ no participaron en la conspiración de silencio, lo que sugiere una comunicación satisfactoria; el 60,9\% estaban recibiendo apoyo espiritual/ religioso, lo que sugiere un apoyo sano y contenido; y todos participaron en rituales fúnebres. Conclusión: El proceso de elaboración del luto de los cuidadores indicó la presencia de factores de protección.

Descriptores: Muerte; Aflicción; Cuidados Paliativos; Cuidadores; Musicoterapia. 


\section{INTRODUCTION}

Bereavement consists on a combination of signals and symptoms responding to the loss of a loved one. It is a singular experience for each person, and its expression depends on the circumstances, context, consequences of the loss for the bereaved person ${ }^{(1)}$, culture, personality, and the meaning given to the loss ${ }^{(2)}$.

Each person experiences the bereavement in a particular way, expressing their grief with stronger or lesser emotion, which makes it impossible to stablish standards for the reaction to the loss of a loved one. It is known that death is felt by the ones who remain alive, and that they need means to express their grief. It is highlighted that the bereavement process cannot be hushed, and that there are no formulas to mitigate the pain, however, one can be present and demonstrated that the bereaved person is not alone, that grieving does not mean weakness, and that it is necessary to experience the loss ${ }^{(3)}$.

In this sense, a study aimed to understand the feelings of family member experiencing grief for the death of a loved one due to cancer and concluded that the family member feel anguished and fearful in face of the imminence of the death of their loved ones, thus discovering their own finitude. It was demonstrated that family members experience the pain due to the absence of their loved ones, mourn their death, internalize the loss, and replace themselves in face of the world(3).

Another study has aimed to understand the meanings of experiencing bereavement for elderly widows, and its relation to religiosity and spirituality has indicated that believing in God may significantly affect the construction of meanings related to the restoration of the loss; that the religion may help in the discrimination in relation to the death of a loved one; and that believing in life after death and the notion of death as a "divine call" may subside the elaboration of the loss ${ }^{(4)}$. Thus, spirituality, religiosity, and religious beliefs have contributed in the signification process of death experiences ${ }^{(5)}$.

It is highlighted the music therapy - the use of music to help achieve a specific change in behavior, feelings, or physiology - integrates the scope of nursing interventions suggested for nursing diagnoses as anxiety, despair, acute pain, chronic pain, spiritual suffering, disposition for increased spiritual well-being, and chronic sadness, as well as for clinical conditions, such as depression, aiming to achieve nursing results as the self-control of anxiety, self-control of depression, pain control, personal well-being, spiritual health, confrontation, humor balance, and psychospiritual comfort state ${ }^{(6)}$.

Post-loss music therapy, that is, when it is carried out after the patient's death, aims to provide bereaved family members social, emotional, and spiritual support in the process of elaborating the loss. Based on that supposition, an investigation has aimed to assess the effects of sacred music, instrumental and chanted ones, on the spiritual well-being of bereaved family members, despite not having statistically significant results, it identified that listening to sacred music tends to improve the levels of spiritual well-being for bereaved family members ${ }^{(7)}$, as well as it helps in the process of elaborating the loss.

Given that, this study adopted as its theoretical references intervening factors for the process of elaborating the loss; protection factors, which can help in preventing complicated bereavement; and risk factors, which can complicate and contribute to the development of complicated bereavement. These are propositions that suggest patterns, but not certainties ${ }^{(2)}$.

Protection factors that can help in preventing complicated factors comprise secure attachment, which gives to the bereaved person more organization and better capacity to integrate new information and which tends to activate more resilience; a relationship without conflicts or unresolved issues, with lesser complicating potential; healthy and continent support (which is adequate, necessary, and enough in the bereaved person's perception) and satisfactory communication; performing rites, which is important for the process of separation and parting, since it helps ending a cycle; anticipatory bereavement (commonly experienced in the context of palliative care), since it allows for the living person to experience the loss without it having effectively happened, subsiding farewells, solving unresolved issues, and the beginning of the construction of new meanings, identities and relations; death due to chronic diseases, without suffering, since it allows time for farewells and the resolution of unresolved issues; bereavement that is recognized by the bereaved person and by society, in which one and the other's pain is valued, allowing the decoding of the meaning of the bereavement for each one, the experience of the bereavement process, sometimes guided by the loss, and other by reparation, and the maintenance of a healthy bond, without necessarily implying on a definite separation; and the resilience, not only as an expression of post-death action, but as a pre-loss one - a strategy that shows the capacity of perceiving, based on skills (flexibility and creativity) to create possible alternatives, according to the personality of the bereaved persons, their sense of competence, and the existence of a secure attachment ${ }^{(2)}$.

Risk factors that may complicate and contribute to the development of complicated bereavement comprise the insecure attachment, expressed by people with more disorganization and contradictions, who are discouraged to evaluate situations and identify coping strategies that tend to repeat failed behavior patterns; conflicted and unresolved relationships, or the existence of dependence between the bereaved person and the loved one with a higher complicating potential; death of children and young people; inadequate, abusive, and insufficient support (in the bereaved person's view) and compromised communication between family member; sudden or violent death, as well as the ones due to acute diseases and suicide, since they do not allow for farewells or adjustments in the relationship, and it can vary according to the meaning and context of the death; not finding the body, and the consequent impossibility of performing wished rites, making it harder to accept the loved one's death; maintenance of the bond to the deceased person or idolatry, impossibility of experiencing the process of death and reparation, making it harder to return to previous activities and the maintenance of its quality, as well as the construction of new meaning based on the new configuration; strict personality; difficulty in adapting to new conditions; psychiatric disorders or depression; life history characterized by multiple and successive losses; being away from the loved one that has the possibility of eminent death - impossibility of expressing feelings and solving 
unresolved matters, which can make the bereaved person feel guilty after the death; death of an espouse - a main stressing event; non-recognized bereavement or non-admitted by the bereaved person (defense strategy) and by the society - not valuing one or the other's pain, breaking with empathy, and preventing the person to experience the bereavement process, which includes the gender issue, socially imposing that men cannot cry, restricting the expression of their feelings ${ }^{(2)}$.

It is important to register that music therapy is a nursing invention that is little used and studied in Brazil, especially in the context of palliative care to the bereaved family. It is believed that post-loss music therapy is a protection factor, that may help prevent complicated bereavements; and that the description of the characteristics of caregivers submitted to post-loss music therapy may guide the design of new interventions and studies.

\section{OBJECTIVE}

To describe the characteristics of bereaved caregivers submitted to post-loss music therapy.

\section{METHOD}

\section{Ethical aspects}

The research project was approved by the Research Ethics Committee of the Nursing School of the Universidade de São Paulo.

\section{Study design, place, and period}

It is a transversal approach to a database of a randomized clinical study ${ }^{(7)}$, performed in the households of bereaved family members, who have lost their loved ones (parents or espouses) due to cancer. The data were gathered between January 2014 and March 2015, through a semi-structured form.

\section{Sample; inclusion and exclusion criteria}

In the process of eligibility for the project, the following inclusion criteria were determined: being bereaved due to the death of a beloved family member (father, mother, or espouse), registered in the Female Network of Combat to Cancer (RFCC) of Maringá - PR - a philanthropic non-profit entity that cares for cancer patients in situation of social vulnerability - whose death was caused by cancer, at least a month and in maximum 12 months before; having taken part in the care process at end of the life of their loved ones; living in the municipalities of Maringá-PR, Sarandi-PR, or Paiçandu-PR; being 18 years old or older; having their hearing function preserved; having their language function preserved. For the exclusion of participants, the following criteria were adopted: family members that moved from the town, with hearing or cognitive difficulties during the intervention. Of the 169 eligible bereaved family member, 33 did not accept joining the research, 59 did not meet the inclusion criteria, five gave participating up before the beginning of data collection, due to lack of time to book visitations, and three were characterized as accompaniment loss, due to the same reason. Thus, data of 69 bereaved family members were analyzed.

\section{Primary study protocol}

Considering the importance of making the readers acquainted to post-loss music therapy, the musical resources used will also be described, respecting the variety and complexity of musical stimuli and other intervening factors. The researchers used three sacred songs, composed by Friar Luz Turra, interpreted by the Imaculada Conceição Choir, and produced by the COMEP recorder: Vossa presença faz viver (triple time: tone D major); Prece ao Deus vivo (quadruple time: tone D major); Quando a dor chegar (quadruple time: tone $\mathrm{G}$ major).

The songs have a moderate progression with little variability; major mode with simple consonant harmony; ascending melodic contour; legato articulation, with little variability and regular rhythm. The method for presenting the songs was live, in a pleasant volume, performed by two of the researchers, a musician and nurse one, with previous clinical experience using music therapy as a nursing intervention, and the other one is a music educator and musician - pianist and flautist.

The materials used in the intervention were: male voice (tenor), acoustic guitar, recorder (contralto), musical repertoire, score rack, chair or sofas. The intervention strategy structured "music listening" in four sessions of 20 minutes each, once a week, since the researchers intended to follow the participants in order to subside a psycho-social-spiritual support through post-loss music therapy, which would probably be impossible in a single session, considering the extension of the process of bereavement elaboration.

\section{Result analysis and statistics}

The information obtained in the database enabled the analysis of the following variables for this study: degree of kinship with the deceased beloved one, gender, schooling levels, marital status, age, bereavement period, religion, importance of religion, frequency attending masses/worship, habit of listening to music, music appreciation, bonds to the beloved one, duration of the death and dying process, circumstances of death, silence conspiration, participation in funeral rites, previous experiences of death/ bereavement, use of antidepressants, social/community support, psychological treatment, spiritual/religious support, and use of integrative and complementary practices. Descriptive statistical analysis were performed (absolute and relative frequency, average, median, and standard deviation) by the software Statistical Package for the Social Sciences (SPSS) (Version 22).

\section{RESULTS}

69 bereaved family members took part in the study, of which 19 (27.5\%) were spouses and 50 (72.5\%) were daughters and sons, with 50 (72.5\%) female participants, 30 (43.5\%) having not finished middle school, 22 (31.9\%) being married or widowers. The average age was 47.8 years old ( $S D \pm 3.5$, median 5 months).

Among the characteristics involved in the participants process of elaborating the bereavement, identified as protection factors according to the adopted theoretical references ${ }^{(2)}$, we highlight the strong attachment (strong bonds to the loved one) (Table 1); performing rites (taking part in funeral rites); and healthy and 
continent support (spiritual/religious support) (Table 2); as well as the death due to chronic disease (cancer).

Almost all participants had previous death/bereavement experiences $(95.7 \%)$, with lack of silence conspiration (88.4\%) and having the duration of the dying process longer than six months for $68.1 \%$ of family members.

Table 1 - Pre-loss characteristics involved in the participants ' process of elaborating the bereavement, Maringa, Paraná, Brazil, 2015

\begin{tabular}{|c|c|c|c|}
\hline Variables & & $\mathbf{n}$ & $\%$ \\
\hline Religion & $\begin{array}{l}\text { Catholic } \\
\text { Protestant }\end{array}$ & $\begin{array}{l}37 \\
32\end{array}$ & $\begin{array}{l}53.6 \\
46.4\end{array}$ \\
\hline Importance of Religion & $\begin{array}{l}\text { Little important } \\
\text { Relatively important } \\
\text { Important } \\
\text { Very important }\end{array}$ & $\begin{array}{c}1 \\
1 \\
2 \\
19\end{array}$ & $\begin{array}{c}4.3 \\
4.3 \\
8.7 \\
82.6\end{array}$ \\
\hline $\begin{array}{l}\text { Frequency going to masses/ } \\
\text { worship }\end{array}$ & $\begin{array}{l}\text { Rarely goes } \\
\text { Sometimes goes } \\
\text { Almost always goes } \\
\text { Always goes }\end{array}$ & $\begin{array}{c}10 \\
13 \\
7 \\
39\end{array}$ & $\begin{array}{l}14.5 \\
18.8 \\
10.1 \\
56.5\end{array}$ \\
\hline Habit of listening to music & $\begin{array}{l}\text { Yes } \\
\text { No }\end{array}$ & $\begin{array}{l}58 \\
11\end{array}$ & $\begin{array}{l}84.1 \\
15.9\end{array}$ \\
\hline Music appreciation & $\begin{array}{l}\text { Classic Music } \\
\text { Country Music } \\
\text { Popular Brazilian Music } \\
\text { Sacred Music } \\
\text { Samba } \\
\text { Rock } \\
\text { Others* }\end{array}$ & $\begin{array}{c}2 \\
19 \\
4 \\
35 \\
1 \\
2 \\
6\end{array}$ & $\begin{array}{c}2.9 \\
27.5 \\
5.8 \\
50.7 \\
1.4 \\
2.9 \\
8.7\end{array}$ \\
\hline Bonds to the loved one & $\begin{array}{l}\text { Weak } \\
\text { Intermediary } \\
\text { Strong }\end{array}$ & $\begin{array}{c}4 \\
6 \\
59\end{array}$ & $\begin{array}{l}5.8 \\
8.7 \\
85.5\end{array}$ \\
\hline $\begin{array}{l}\text { Duration of the death and dying } \\
\text { process }\end{array}$ & $\begin{array}{l}\text { Short ( } \leq 6 \text { months) } \\
\text { Long ( }>6 \text { months) }\end{array}$ & $\begin{array}{l}22 \\
47\end{array}$ & $\begin{array}{l}31.9 \\
68.1\end{array}$ \\
\hline Silence conspiration & $\begin{array}{l}\text { Yes } \\
\text { No }\end{array}$ & $\begin{array}{c}8 \\
61\end{array}$ & $\begin{array}{l}11.6 \\
88.4\end{array}$ \\
\hline Death circumstance & $\begin{array}{l}\text { At home } \\
\text { At the hospital }\end{array}$ & $\begin{array}{l}18 \\
51\end{array}$ & $\begin{array}{l}26.1 \\
76.9\end{array}$ \\
\hline $\begin{array}{l}\text { Previous death/bereavement } \\
\text { experiences }\end{array}$ & $\begin{array}{l}\text { Yes } \\
\text { No }\end{array}$ & $\begin{array}{c}66 \\
3\end{array}$ & $\begin{array}{c}95.7 \\
4.3\end{array}$ \\
\hline
\end{tabular}

Note: ${ }^{*}$ Others: all/no specific genre: $4(5,8 \%)$; electronic: $1(1,4 \%)$; depends on the state of mind: $1(1,4 \%)$.

Table 2 - Post-loss characteristics involved in the participants' process of elaborating the bereavement, Maringá, Paraná, Brazil, 2015

\begin{tabular}{|c|c|c|c|}
\hline Variables & & $\mathbf{n}$ & $\%$ \\
\hline Taking part in funeral rites & $\begin{array}{l}\text { Yes } \\
\text { No }\end{array}$ & $\begin{array}{c}69 \\
-\end{array}$ & $\begin{array}{c}100 \\
-\end{array}$ \\
\hline Use of antidepressants & $\begin{array}{l}\text { Yes } \\
\text { No }\end{array}$ & $\begin{array}{c}4 \\
65\end{array}$ & $\begin{array}{c}5.8 \\
94.2\end{array}$ \\
\hline Community/social support & $\begin{array}{l}\text { Yes } \\
\text { No }\end{array}$ & $\begin{array}{l}17 \\
52\end{array}$ & $\begin{array}{l}24.6 \\
75.4\end{array}$ \\
\hline Psychological treatment & $\begin{array}{l}\text { Yes } \\
\text { No }\end{array}$ & $\begin{array}{c}7 \\
62\end{array}$ & $\begin{array}{l}10.1 \\
89.9\end{array}$ \\
\hline Spiritual/religious support & $\begin{array}{l}\text { Yes } \\
\text { No }\end{array}$ & $\begin{array}{l}42 \\
27\end{array}$ & $\begin{array}{l}60.9 \\
39.1\end{array}$ \\
\hline Use of integrative and complementary practices & $\begin{array}{l}\text { Yes* } \\
\text { No }\end{array}$ & $\begin{array}{c}1 \\
68\end{array}$ & $\begin{array}{c}1.4 \\
98.6\end{array}$ \\
\hline Total & & 69 & 100 \\
\hline
\end{tabular}

Note: *Reiki.
As the project proposed to apply a musical intervention, characteristics related to music appreciation were also assessed. Most participants had the habit of listening to music (84.1\%), and the most preferred music style was sacred music (50.7\%), followed by country music (27.5\%).

\section{DISCUSSION}

The first data capturing the attention in the presentation of results constitutes, according to the adopted theoretical references, a risk factor for complicated bereavement - death of a spouse -, considered as the main stressing event. However, it is believed that, besides being related to the process of elaborating the bereavement of only 19 (27.5\%) participants, protection factors overlapped it.

Considering the well-being scores of the 69 participants, before and after post-loss music therapy, which indicated high Spiritual Well-Being and Religious Well-Being (RWB) levels, and moderate to high Existential Well-Being (EWB) levels, it is confirmed the perception that the risk factor "death of a spouse" did not affect significantly the process of elaborating the bereavement for these 19 participants.

It is highlighted that the RWB refers to the vertical dimension of spirituality and it is related to the person's satisfaction regarding their connection to God or something transcending human dimensions, and that it has presented positive association to inner strength and hope, and negative associations to depression and loneliness. EWB, in its turn, is related to the horizontal dimension of spirituality and it refers to the person's perception regarding the meaning and sense of life, regardless of a religious reference ${ }^{(8)}$. In this sense, nurses must develop an attentive look towards these matters, being trained in specific spiritual anamnesis protocols and seizing real care moments to strengthen patients ${ }^{(9)}$ and their family members.

Regarding religious beliefs, it was observed that the sample was exclusively comprised by Christians, catholic and protestant ones, with the majority of them giving a lot of significance to religion, and more than half of it reported always going to masses/ worship cults, liking listening to sacred music and being receiving spiritual/religious support. Effectively, religious beliefs have positively affected the elaboration of bereavement ${ }^{(4)}$, subsidizing the confrontation of adversity and traumatic and stressful events ${ }^{(10)}$.

Contextualizing, there is a study that aimed to identify prevailing themes on religion, disease, and death in the life stories of families that lived with an ill loved one, and to examine the relation between religious beliefs, diseases, and death, which concluded that beliefs significantly integrate the lives of many families, promoting social, emotional and spiritual support, and which, therefore, cannot be neglected in the process of disease and death ${ }^{(5)}$, as well as in the bereavement process.

It is highlighted that music is a common characteristic of funerals, both sacred and popular ones, when the funeral is personalized for the deceased person. Five specific uses of music in this context are suggested: music as a means of control; music as a means of inclusion and exclusion; music as a source of collective activity; music as the means for creating or changing emotions; and music as the means to evoke the memory of the deceased person ${ }^{(11)}$. In this sense, it is 
evinced the significant role of music in oriental religions - Hinduism, Sikhism, and Buddhism - as well as in western religions - Judaism, Christianism, and Islam ${ }^{(12)}$, once its association to liturgy may evoke religious feelings, wherever it may come from ${ }^{(13)}$. Indeed, songs, singing and/or other harmonious stimuli catalyze the spiritual potency of prayer by accessing directly the spiritual self(12).

Prayer represents a strategy that subsides the implementation of some Nursing Interventions suggested in the Nursing Interventions Classification (NIC) - Spiritual Support; Spiritual Growth Facilitation; and Religious Ritual Enhancement ${ }^{(6)}$, capable of meeting spiritual needs of patients, calming them down ${ }^{(14)}$. Spiritual Support is the assistance to patients so that they will have balance and connection to a higher power; Spiritual Growth Facilitation constitutes the facilitation of the growth of the patients' capacity in identifying, connecting, and calling to a source of meaning, finality, comfort, strengthening, and hope for their lives; and Religious Ritual Enhancement is the facilitation of participation in religious practices ${ }^{(6)}$.

According to this way of thinking, a systematic review was developed with the intent of summarizing scientific evidences on the effect and applicability of interceding prayers in the recovery of patients' health. Although the methodological description of the studies analyzed - type of prayer, its frequency and duration - is insufficient to indicate its replication and incorporation in clinical practice, the authors have concluded that interceding prayers must be used in health care; that prayers are always beneficial, not exerting any negative influences; and that there are Nursing resources for using $\mathrm{it}^{(15)}$.

It is highlighted the qualitative study carried out in Tanzania with 17 professionals involved in palliative care (eight nurses, seven chaplains, and two social assistants), in which the results revealed that songs with hopeful messages bring comfort to patients, and that this music style may help the person to die in peace ${ }^{(16)}$.

Regarding the care process it was evinced that most participants had a strong bond with their deceased loved one (protection factor), which may be related to a relationship without conflicts and unresolved issues; they also accompanied a long dying and death process, which is directly related to the death due to chronic diseases (protection factor), enabling time for farewells, and the resolutions of questions and unresolved issues; as well as they did not participate in silence conspiration - suggesting a satisfactory communication (protection factor).

As for the process of loss and reparation, all have taken part in funeral rites (protection factor), which is important for the process of separation and farewell, helping to close the cycle; almost all of them had experienced bereavement for the loss of another loved one; and most of them reported receiving religious/spiritual support - suggesting a health and continent support, which is adequate, necessary and sufficient in the bereaved person's view (protection factor). A high percentage of family members have also reported following the proposed medical treatment.

Therefore, it is concluded that such experiences have contributes to the current process of elaborating the bereavement, considering that the results indicate that the family members were experiencing a feeling of mission accomplished, of having done what was possible, what they could do. The participation of all family members in funeral rites, the fact that only four participants are using antidepressants, and that only seven of them are undergoing psychological treatment may confirm this perception.

Accompanying a long death and dying process, a condition experienced by most participants, implies on living a gradual and progressive loss (anticipatory bereavement - protection factor), experienced due to the functional and clinical decline of the loved one, due to the evolution of the disease. It is a moment of great suffering, but also of great faith and hope in God, preparing them to face post-death bereavement with serenity, avoiding complicated bereavements.

However, the "anticipatory bereavement", just as the "bereavement phases" and the "experience of care in the last days of life" were not dully investigated in this study. Yet, most family members under palliative care experienced anticipatory bereavement, that is, they experienced the loss even before it happened, thus allowing for farewells, solving unresolved matters, and for the construction of new meanings, identities, and relationships ${ }^{(2)}$.

It is believed that another protection factor - the bereavement being recognized by the bereaved person and by society - may have been experienced by 46 (66.7\%) participants during post-loss music therapy (experimental groups), in which bereaved people may recognize their pain, with the help of music, and their pain may be valued through the compassionate presence of the nurse, creating resilience (another protection factor), and contributing to the process of elaborating the bereavement.

Effectively, music therapy enables the expression of thoughts and feelings, the recovery of reminiscence, the exchange of smiles, visual contact, and touch ${ }^{(17)}$; and the compassionate and active and welcoming listening of the nurse may help the family in the process of reorganizing the life and adapting to the changes caused by the loss, reducing inefficient responses ${ }^{(18)}$.

It is important to highlight that most participants reported not having received social/community support. In this context, the results of the qualitative study that interviewed 42 bereaved family members for the death of hypertension patients, due to cerebrovascular diseases, with the intent of identifying how they perceived the assistance given in primary care, confirm the results found here. It was observed that families did not receive any visits of the Family Health Strategy (ESF) team during the bereavement process, probably due to professionals being unprepared to assist them in this moment ${ }^{(19)}$.

It is highlighted that the lack of empathy and social support, and the exclusion from religious or social rites, tend to intensify emotional reaction and to contribute to the development of complicated bereavement ${ }^{(20)}$, given that the family members' capacity in dealing with the death of their loved ones depends on their own psychological and physical conditions, but also on their support network ${ }^{(21)}$. Thus, given the lack of support, the bereaved family experiences an "emptiness", evincing the need for continuing the care after the death of their loved ones ${ }^{(22)}$, set as a risk factor for the process of elaborating the bereavement. Despite $75.4 \%$ of participants having reported not receiving social/ community support, it is believed that the spiritual/religious support, reported by $60.9 \%$ of participants, may have met this deficit.

Although experiencing the death of the loved one in the hospital, a circumstance reported by most participants, may suggest a positive attitude in relation to the assistance given to the patient 
in the death and dying process, which may be true considering the Brazilian reality in relation to the offer of palliative care, it is important to recall that the palliative philosophy recommends the death in the household, where the patients have the opportunity of dying besides their family members, accepting it as a natural process, inherent to the cycle of life, in detriment of being submitted to procedures aiming to prolongate life, but also the suffering.

It is highlighted that only one participant reported being using Reiki (a complementary integrative practice). This result may be related both to the low offer and unawareness by the population, and to the possibility of participants considering it unnecessary, considering protection factors inherent to the mentioned process of elaborating the bereavement, which seems unlikely. Thus this study is highlighted as an innovative initiative, by offering postloss music therapy to bereaved family members.

Considering that the National Policy of Complementary and Integrative Practices in the Brazilian Unified Health System (PNPIC) was instituted in 2006; that, in 2016, 2,203,661 individual consultations and 224,258 collective activities, involving more than 5 million people; that, in 2017, they were offered in 8,200 Basic Health Units (UBS), distributed in 3,018 municipalities; and, overall, that music therapy was incorporated to the PNPIC by the Decree no. 849, of the $27^{\text {th }}$ March 2017, it is evinced that the offer of complementary and integrative practices is still little widespread, given that it is offered by only $19 \%$ of UBSs and by $54 \%$ of Brazilian municipalities ${ }^{(23)}$.

\section{Study limitations}

As the limitations of this study, it is registered the fact that it was carried out with Christian bereaved family members, who conferred great importance to religion, always going to masses or worship cults, having the habit of listening to sacred music, that is, people whose spirituality favored the elaboration of bereavement, specially due to involving family members whose life history reveals the presence of protection factors for complicated bereavement. On the other hand, it is evinced the exclusion of family members experiencing bereavement due to the death of other loved ones (children, grandparents, uncles, aunts, siblings); the non-previous classification of the participants in relation to the phases of bereavement, or to risk factors for complicated bereavement; and the difficulty to stablish a homogenous sample.

\section{Contributions for the Nursing and Health areas}

The study presents a care scenario that is little explored by Brazilian Nursing, evincing post-loss music therapy as a Nursing Intervention to the bereaved family, with results that may guide the design of new studies, mixed or qualitative ones, which allow for the access to subjectivity, covering in their inclusion criteria: family members in bereavement for less than a month (regardless of degree of kinship or family composition); who give little importance to religion; who rarely go to masses or worship cults; who do not have the habit of listening to sacred music; who have accompanied short death and dying processes (< 6 months); whose histories reveal the presence of risk factors for complicated bereavement; as well as the classification in relation to bereavement phases.

\section{CONCLUSION}

It was observed that bereaved family members were Christians, most of them conferring great importance to religion, regularly going to masses or worship cults, having the habit of listening to sacred music, and having gone through previous death and bereavement experiences in the family. Regarding protection factors in the process of elaborating the bereavement, most family members had a strong bond/secure attachment to their deceased loved ones; having accompanied a long death and dying process, which is directly related to the death due to chronic diseases and allows for time for farewells and solving unresolved matter; not having participated on silence conspiration - suggesting a satisfactory communication; having participated in funeral rites; having received spiritual/religious support - suggesting healthy and continent support.

Besides religious beliefs, previous sound-musical experiences and the experiences inherent to the processes of care and death and dying may have also been contributing factors to the participants' process of elaborating the bereavement.

\section{REFERENCES}

1. Shear MK, Muldberg S, Periyakoil V. Supporting patients who are bereaved. BMJ. 2017;358:j2854. doi: 10.1136/bmj.j2854

2. Braz MS, Franco MHP. Profissionais paliativistas e suas contribuições na prevenção de luto complicado. Psicol Cienc Prof. 2017;37(1):90-105. doi: 10.1590/1982-3703001702016

3. Santos EM, Sales CA. Familiares enlutados: compreensão fenomenológica existencial de suas vivências. Texto Contexto Enferm. 2011;20(esp.):214-22. doi: 10.1590/S0104-07072011000500027

4. Farinasso ALC, Labate RC. Luto, religiosidade e espiritualidade: um estudo clínico-qualitativo com viúvas idosas. Rev Eletr Enf. 2012;14(3):588-95. doi: 10.5216/ree.v14i3.14453

5. Bousso RS, Poles K, Serafim TS, Miranda MG. Religious beliefs, illness and death: family's perspectives in illness experience. Rev Esc Enferm USP. 2011;45(2):391-7. doi: 10.1590/S0080-62342011000200014

6. Johnson M, Moorhead S, Bulecheck G, Butcher H, Maas M, Swanson E. Ligações NANDA - NIC - NOC: condições clínicas: suporte ao raciocínio e assistência de qualidade. Rio de Janeiro: Elsevier; 2012.

7. Silva VA, Silva RCF, Cabau NCF, Leão ER, Silva MJP. Effects of sacred music on the spiritual well-being of bereaved relatives: a randomized clinical trial. Rev Esc Enferm USP. 2017;51:e03259. doi: 10.1590/s1980-220×2016009903259 
8. Marques LF, Sarriera JC, Dell'Aglio DD Adaptação e validação da Escala de Bem-estar Espiritual (EBE). Aval Psicol [Internet]. 2009 [cited 2017 Dec 27];8(2):179-86. Available from: http://pepsic.bvsalud.org/pdf/avp/v8n2/v8n2a04.pdf

9. Bezerra SMMS, Gomes ET, Galvão PCC, Souza KV. Spiritual well-being and hope in the preoperative period of cardiac surgery. Rev Bras Enferm. 2018;71(2):398-405. doi: 10.1590/0034-7167-2016-0642

10. Kimura M, Oliveira AL, Mishima LS, Underwood LG. Cultural adaptation and validation of the Underwood's Daily Spiritual Experience Scale: Brazilian version. Rev Esc Enferm USP. 2012;46(spe):99-106. doi: 10.1590/S0080-62342012000700015

11. Caswell G. Beyond words: some uses of music in the funeral setting. Omega (Westport). 2012;64(4):319-34. doi: https://doi.org/10.2190/ OM.64.4.C

12. Cantz P. A psychodynamic inquiry into the spiritually evocative potential of music. Int Forum Psychoanalysis. 2013;22(2):69-81. doi: 10.1080/0803706X.2012.657673

13. Goldman DP. Sacred music, sacred time. First Things [Internet]. 2009 [cited 2017 Dec 27]. Available from: https://www.firstthings.com/ article/2009/11/sacred-music-sacred-time

14. Carvalho CC, Chaves ECL, lunes DH, Simão TP, Grasselli CSM, Braga CG. Effectiveness of prayer in reducing anxiety in cancer patients. Rev EsC Enferm USP. 2014;48(4):684-90. doi: 10.1590/S0080-623420140000400016

15. Carvalho CC, Silva RP, Chaves ECL, Caldeira S. Preces intercesoras: Efecto en la recuperación de la salud de personas en tratamiento médico. Index Enferm. 2013;22(3):186-90. doi: 10.4321/S1132-12962013000200017

16. Hartwig R. Music therapy in the context of palliative care in Tanzania. Int J Palliat Nurs. 2010;16(10):499-504. doi: 10.12968/ ijpn.2010.16.10.79215.

17. O'Callaghan C. Music, health and loss throughout the ages: a precursor to music therapy in palliative care. Austral - Asian J Cancer [Internet]. 2010 [cited 2017 Dec 27];9(3):157-66. Available from: http://www.australasiancancer.org/journal-article-view/ music-health-and-loss-throughout-the-ages-a-378

18. Silva VA, Silva RCF, Trovo MM, Silva MJP. Roy's adaptation model and the dual process model of grieving substantiating palliative nursing care to the family. Mundo Saude. 2017;40A:521-36. doi: 10.15343/0104-7809.201740A521536

19. Barreto MS, Silva RLDT, Waidman MAP, Marcon SS. Percepção da família sobre a assistência a pessoas com hipertensão arterial que foram a óbito. Rev Eletr Enf. 2013;15(1):162-71. doi: 10.5216/ree.v15i1.19085

20. Bousso RS, Ramos D, Frizzo HCF, Santos MR, Bousso F. Facebook: um novo locus para a manifestação de uma perda significativa. Psicol USP. 2014;25(2):172-9. doi: 10.1590/0103-656420130022

21. Woźniak K, lżycki D. Cancer: a family at risk. Prz Menopauzalny. 2014;13(4):253-61. doi: 10.5114/pm.2014.45002

22. Harrop E, Morgan F, Byrne A, Nelson A. "It still haunts me whether we did the right thing": a qualitative analysis of free text survey data on the bereavement experiences and support needs of family caregivers. BMC Palliat Care. 2016;15(1):92. doi: 10.1186/s12904-016-0165-9

23. Ministério da Saúde (BR). Glossário Temático: práticas integrativas e complementares em saúde [Internet]. Brasília: Ministério da Saúde; 2018 [cited 2018 Dec 27]. Available from: http://portalarquivos2.saude.gov.br/images/pdf/2018/marco/12/glossario-tematico.pdf 